DIÁLOGO DE POETAS

\title{
GAVIOTAS
}

\section{Casi casi blanco}

$$
\text { verde azul el mar }
$$

la casa parece blanca

árbol adentro

$$
\text { y cielo arriba y cielo adentro }
$$

se van del mar

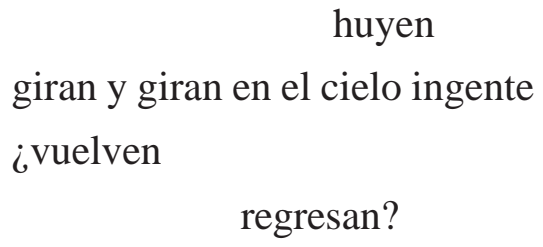

No a la playa

no al verde del árbol de noche oscura

$$
\text { y luz de noche }
$$

iluminan el vuelo

Cerca de la arena

$$
\text { cruje }
$$$$
\text { arena en la playa }
$$

¿dónde está?

$$
\begin{aligned}
& \text { ¿dónde está? } \\
& \text { la blanca gaviota blanca }
\end{aligned}
$$

Hostal de la Gaviota, S’Agaró, Noviembre de 2003 